\title{
The difference of salivary ph before and after toothbrushing with toothpaste containing betel leaf (Piper Betle)
}

\author{
Soo Ling Fu, Silvi Kintawati, Sri Tjahajawati \\ Department of Oral Biology Faculty of Dentistry Universitas Padjadjaran
}

\begin{abstract}
There has been a long history of the use of plants to improve dental health and oral hygiene. The purpose of this research was to find out the difference of salivary $\mathrm{pH}$ before and after toothbrushing with toothpaste containing betel leaf (Piper betle). The type of research used was quasi- experimental. Data collected was analysed by using paired $t$ test. The result shows that there is an increase of salivary pH by an average of 0.48 after toothbrushing with toothpaste containing betel leaf (Piper betle). In conclusion, there is difference between the salivary $\mathrm{pH}$ before and after toothbrushing with toothpaste containing betel leaf (Piper betle).
\end{abstract}

Keywords: Betel leaf (Piper betle), Salivary pH

\section{ABSTRAK}

Penggunaan tanaman untuk meningkatkan kesehatan gigi dan kebersihan mulut telah diperkenalkan sejak zaman dahulu. Tujuan penelitian adalah untuk mengetahui perbedaan $\mathrm{pH}$ saliva sebelum dan sesudah menyikat gigi dengan pasta gigi yang mengandung daun sirih (Piper betle). Jenis penelitian bersifat eksperimental semu. Data dianalisis dengan statistik uji $t$ berpasangan. Hasil penelitian menunjukkan bahwa terjadi peningkatan $\mathrm{pH}$ saliva dengan rata-rata 0,48 sesudah menyikat gigi dengan pasta gigi yang mengandung daun sirih (Piper betle). Simpulan dari penelitian menunjukkan bahwa terdapat perbedaan $\mathrm{pH}$ saliva sebelum dan sesudah menyikat gigi dengan pasta gigi yang mengandung daun sirih (Piper betle).

Keywords: Daun sirih (Piper betle), pH saliva

\section{INTRODUCTION}

There is a long history of the use of plants to improve dental health and oral hygiene. Lewis and Elvin-Lewis noted the effect of the Islamic culture tooth-brushing by Miswak throughout many countries in Asia and Africa. ${ }^{1}$ In recent years, emphasis of research has been on utilizing the traditional medicines that have a long and proven history of treating various ailments for example Neem, Miswak and betel leaf (Piper betel). ${ }^{2}$

Betel leaf (Piper betle) belongs to the family Piperaceae. The betel plant is a slender, aromatic creeper, rooting at the node. It has an alternate, 
heart shaped, smooth, shining and long stalked leaves with pointed apex. Betel is originated from central and eastern part of Malaysia. It spreads at a very early date throughout tropical Asia and east Africa. It is widely cultivated in many parts of India. ${ }^{3}$

The volatile oil known as essential oil is the main constituent of the betel leaf (Piper betle). ${ }^{4}$ The hydroxychavicol is said to exhibit antibacterial activity by affecting the ultrastructure of Streptococcus mutans and reducing their acid producing activity. ${ }^{5}$ The antimicrobial potential of essential oil against tested pathogen concludes that it may be a source of antimicrobial agent for dental caries in commercial toothpaste. ${ }^{6}$ Other than that, betel leaf (Piper betle) can be used as an antiplaque agent. ${ }^{7}$

Betel leaf (Piper betle) has a distinctive aroma that is spicy, pungent, and sharp which caused by chavicol and bethelphenol. The spicy aroma and taste contained in the betel leaf stimulates the olfactory and taste systems. This increases the secretion of saliva, which also increases the saliva buffer capacity and lastly increasing of salivary $\mathrm{pH}^{8}$

Equipments and materials, List of equipments and materials that used to conduct the research are herbal toothpaste that contains betel leaf (Piper betle), plastic container, digital $\mathrm{pH}$ meter, stop watch, water, mask and gloves, explorer and mouth mirror, tissue paper, buffer solution $\mathrm{pH} 4$ and $\mathrm{pH} \mathrm{7,} \mathrm{examination} \mathrm{form} \mathrm{and}$ informed consent.

\section{MATERIALS AND METHODS}

Before measuring $\mathrm{pH}$ of saliva, calibration of $\mathrm{pH}$ meter should be performed to obtain more accurate $\mathrm{pH}$. After calibration of $\mathrm{pH}$ meter is performed, we can proceed to the experiment. All the samples are instructed to fast for 2 hours before experiment is done on them. The student is asked to brush his or her teeth only with toothbrush without toothpaste for 2 minutes then gargle with water.

Toothbrushing method used is rolling stroke method and amount of toothpaste used is about the size of pea. ${ }^{9}$ Then, he or she is instructed to sit and bend his or her head to allow saliva to accumulate in their mouth for 5 minutes. After 5 minutes, the student is instructed to spit out the saliva in a plastic container. Lastly, test the $\mathrm{pH}$ value of saliva using digital $\mathrm{pH}$ meter and record the result in examination form. After resting for 30 minutes, repeat the procedures with toothpaste that contains betel leaf (Piper betle). The result is analysed to determine the effect of toothpaste containing betel leaf (Piper betle) to salivary $\mathrm{pH}$.

\section{RESULT}

Diagram 1. Mean of salivary ph before and after toothbrushing with toothpaste containing betel leaf (Piper betle)

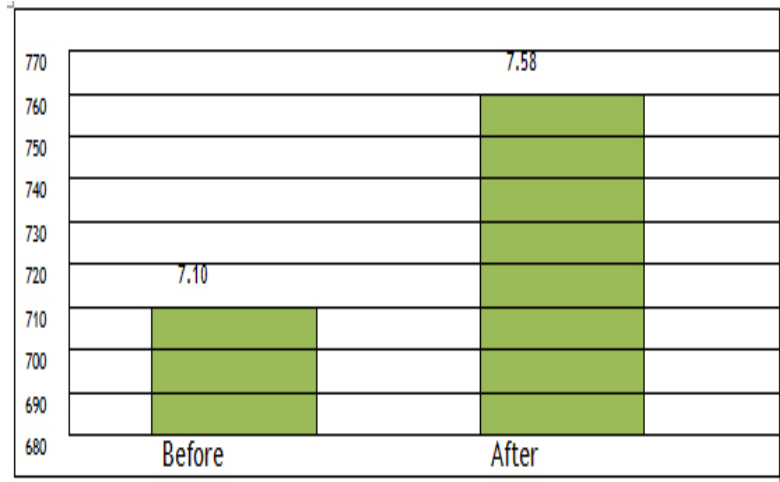

The Diagram above shows that the mean of salivary $\mathrm{pH}$ after toothbrushing with toothpaste containing betel leaf (Piper betle) (7.58) is higher compared to the mean of salivary $\mathrm{pH}$ before toothbrushing with toothpaste containing betel leaf (Piper betle) (7.10). This shows that toothpaste containing betel leaf (Piper betle) is proven to be effective in increasing salivary $\mathrm{pH}$.

Table 1. Difference test of salivary ph before and after toothbrushing with toothpaste containing betel leaf (Piper betle).

\begin{tabular}{lccccc}
\hline \multicolumn{1}{c}{ Comparison of Salivary pH } & $\mathrm{n}$ & gain & $\mathrm{t}_{\text {obstained }}$ & $\mathrm{t}_{\text {critical }}$ & Outcome \\
\hline $\begin{array}{l}\text { Before and After } \\
\text { Toothbrushing }\end{array}$ & 30 & 0,483 & $-12,593$ & $-2,045$ & Ho is rejected \\
\end{tabular}


Based on the table above, it can be seen that the value of is -12.593 . This value will be compared with the value of which is taken from the t-distribution table. With $a=0.05, \mathrm{df}=29$, value obtained is \pm-2.045 . The table above shows that the value of is $(-12.593)$ which is greater than value of (-2.045). According to criteria of hypothesis test, $\mathrm{HO}$ is rejected if $\mathrm{T}_{\text {obtaned }} \mathrm{T}_{\text {critical }}$. This indicates that there are significant differences between the salivary $\mathrm{pH}$ before and after toothbrushing with toothpaste containing betel leaf (Piper betle).

\section{DISCUSSION}

Based on the result of this research, it showed that there are significant differences between the salivary $\mathrm{pH}$ before and after toothbrushing with toothpaste containing betel leaf (Piper betle). The mean of salivary $\mathrm{pH}$ after toothbrushing with toothpaste containing betel leaf (Piper betle) (7.58) is higher compared to the mean of salivary $\mathrm{pH}$ before toothbrushing with toothpaste containing betel leaf (Piper betle) (7.10). This showed that there was an increase of salivary $\mathrm{pH}$ by an average of 0.48 after toothbrushing with toothpaste containing betel leaf (Piper betle).

According to Amerongen, the $\mathrm{pH}$ of saliva is affected by a few factors. Firstly, the factor that affects the $\mathrm{pH}$ of saliva is time. When a person wakes up from resting state, the $\mathrm{pH}$ of saliva is initially high and it will decrease shortly after a few minutes. Similarly, 15 minutes after having meal, the $\mathrm{pH}$ of saliva increases due to mechanical stimulation, but will decrease after half an hour. ${ }^{8}$ Due to these fluctuations in salivary $\mathrm{pH}$, all the samples were asked to fast for 2 hours before experiment was performed on them. On the other hand, little saliva is produced during night time. Hence, the author chose not to conduct the experiment at night time because it might affect the $\mathrm{pH}$ of saliva due to decreased amount of saliva produced. Based on the reasons stated, the author decided to do the research in between 2 to 4 o'clock in the afternoon because according to Ekstrom, et al., the peak of salivary secretion is in the middle of afternoon at around 3 o' clock. ${ }^{10}$

Next, the rate of salivary flow is also one factor that will affect the $\mathrm{pH}$ of saliva. Based on the result of this research, there was an increase of salivary $\mathrm{pH}$ by an average of 0.48 after toothbrushing with toothpaste containing betel leaf (Piper betle). This is attributed to both the mechanical and chemical stimulation of toothbrushing with toothpaste containing betel leaf (Piper betle). Mechanical stimulation is caused by repeated toothbrushing movement which triggers more secretion of saliva and at the same time increases the concentration of bicarbonate ions. The higher the concentration of bicarbonate ions, the higher the salivary $\mathrm{pH}$ will be. As for chemical stimulation, it is caused by the spicy aroma and taste contained in the betel leaf (Piper betle) due to the present of aromatic compound and stable oils like phenols and terpene. These aromatic odor and sharp burning taste are able to stimulate the olfactory and taste system. Due to the effect of chemical stimulation after toothbrushing with toothpaste containing betel leaf (Piper betle), there is an increased secretion of saliva. This leads to increased salivary flow rate and thereby increases the $\mathrm{pH}$ of saliva.

The last factor that affects the $\mathrm{pH}$ of saliva is diet. To ensure the accuracy of this experiment, all the samples were asked to fast for 2 hours before the experiment was conducted on them because according to Amerongen, food rich in carbohydrate, protein or fiber can all affect the salivary $\mathrm{pH}$ respectively. Food rich in carbohydrates will decrease the $\mathrm{pH}$ of saliva because carbohydrate increases the acid production by oral bacteria whereas diets rich in vegetables and protein increase the buffer capacity of saliva and will induce the production of alkaline substances such as ammonia. Therefore, the samples were not allowed to eat any food at least 2 hours before the experiment is conducted on them. Beside that, student who was under medication was not allowed to participate in this research because many classes of drugs for example antidepressants, antihypertensive and antibiotics may reduce the salivary flow rate and will eventually affect the result of this research.

Toothbrushing with toothpaste containing betel leaf (Piper betle) can reduce the risk of tooth decay. This can be explained from the result of this research where the $\mathrm{pH}$ of saliva increased by an average of 0.48 after toothbrushing with toothpaste containing betel leaf (Piper betle). Toothbrushing with toothpaste containing betel leaf (Piper betle) will create a more alkaline 
condition where bacteria that involve in plaque formation such as Streptococcus mutans cannot survive in this condition since they need an acidic environment to survive. By reducing the acidity of oral cavity, bacteria that involve in plaque formation will be eliminated. As a result, tooth decay can be prevented. These validate the beneficial role of betel leaf (Piper betle) in oral hygiene and its potential as antiplaque and anticaries agent.

This research showed that toothbrushing with toothpaste containing betel leaf (Piper betle) for 2 minutes had significant difference in the $\mathrm{pH}$ of saliva, thus the author would like to assume that long term usage of toothpaste containing betel leaf (Piper betle) will provide better effect on the person's oral hygiene. As mentioned above, toothpaste containing betel leaf (Piper betle) showed antiplaque and anticaries properties, therefore it is recommended to be used by the society. Besides that, this toothpaste is recommended to be used by smokers and people who is having bad breath because its spicy aroma and taste can help to prevent mouth odor. Since toothpaste containing betel leaf (Piper betle) is very beneficial, dental professionals should recommend and promote the usage of toothpaste containing betel leaf (Piper betle) to the society.

\section{ACKNOWLEDGMENT}

I wish to extend my sincere appreciation to all those who have helped me and by the grace of God, I was able to complete this article. I would like to express my heartfelt gratitude to Prof. Dr Eky S. Soeria Soemantri, drg., Sp. Ort (K), as the Dean of Faculty of Dentistry, Universitas Padjadjaran, all the staffs of Oral Biology Department, Faculty of Dentistry Universitas Padjadjaran, for their overwhelming cooperation and allowing this article to be done. May God bless all of them, for all the contribution that they had made for this article to be completed. I wish this article will be meaningful for education purpose in the future.

\section{REFERENCES}

1. Walter HL, Elvin-Lewis. Medical Botany-Plants Affecting Human Health. $2^{\text {nd }}$ ed. NJ, USA. 2003.

2. Ismail MYM, Assem NM, Zakriya M. Botanicals promoting oral and dental hygiene. Res $\mathrm{J}$ Pharmac Biol Chem Sciences. 2010;1(2):205.

3. Sandeep KE. A novel neural network based approach for the classification of betel leaves. Inter J Emerg Trends Tech in Comp Scie. 2012;1(2):10.

4. Gandhi MS, Sugumaran M, Comparison of GCMS analysis and anti microbial activity volatile oil in three varieties of Piper Betle $L$ leaves. Intern J Pharm Res. 2012;1(1):1-7.

5. Nalina T, Hahim ZHA. The crude aqueous extract of Piper betle $\mathrm{L}$. and its antibacterial effect towards Streptococcus mutans. Am J Biotechnology and Biochemistry. 2007;3(1):1015.

6. Sugumaran M, Suresh GM, Sankarnarayanan. Chemical composition and antimicrobial activity of vellaikodi variety of Piper betle linn leaf oil against dental pathogen. Intern J Pharm Res. 2011;3(4):2135-9.

7. Lingappa A, Nappalli D, Sujatha GP. Areca nut: To chew or not to chew. J Dent. 2011. p. 214.

8. Amerongen AVN. Ludah dan kelenjar ludah; Arti bagi kesehatan gigi. Yogyakarta: Gajah Mada University Press. 1991. p. 1-22.

9. Mohammad AR. Dental and oral health (seniors). Daily Oral Hygiene Routine. www. netwellness.org. [acces 23 Nov 2012].2011.

10. Ekstrom J, Khasravani N, Castagnola M. Saliva and the control of itssecretion. Italy. 2012.p. 23. 